\title{
XLI. Preparation of a new luting proper to be used in all chemical operations
}

\section{Paysse}

To cite this article: C. Paysse (1803) XLI. Preparation of a new luting proper to be used in all chemical operations, Philosophical Magazine Series 1, 16:63, 236-237, DOI: 10.1080/14786440308676334

To link to this article: http://dx.doi.org/10.1080/14786440308676334

曲 Published online: 18 May 2009.

Submit your article to this journal $\sqsubset \pi$

Џll Article views: 1

Q View related articles $\widetilde{ }$ 


\section{$\left[\begin{array}{ll}236 & ]\end{array}\right.$}

XLI. Preparation of a new Luting proper to be used in all chemical Operations, $B y$ C. PAYsse, Professor of Chemistry*.

$I_{T}$ is generally admitted that the rapid progress which chemistryhas made during the last twenty years, is in part owing to the different kinds of apparatus invented by the immortal Lavoisier, and the precautions employed in the art of luting. In this point of view lutings have been of essential service to chemists, since by facilitating the condensation of many aëriform products they have afforded us the means of determining their nature, and appreciating their volume as well as their gravity. This truth did not escape the sagacity of the celebrated chemist Chaptal, who in his Elements of Chemistry says: "On the art of luting an apparatus properly the whole success of an operation depends."

Among the substances most used for this purpose, are reckoned the fat luting paste of almonds or of linseed, the oil of which is extracted, and mixed with strong glue, and that of the white of eggs, and new cheese united to lime. These different kinds of luting are attended with inconver niences which render them improper for being employed under all circumstances. Fat luting for example, composed of dry clay and oil, combined with an oxide of lead, cannot be applied hut on parts which receive a weak inpression from the heat; for they liquefy at a low temperature, soon run, and consequently become unfit for the proposed end : that of linseed and almonds, mixed with glue or gelatine, is often too porous, easy to be destroyed by acids, and by ammonia, when in a gaseous state: those prepared with the white of eggs, and cheese, mixed with lime, are only attended with the inconveniency of becoming too soon solid, and immediately after mixture; so that it is exceed. ingly difficult to apply them.

The necessity I was under, in preparing oxygenated muriatic acid on a large scale, to find a luting which to the advantage of being cheap should unite that of being soon prepared, and of resisting the destructive action of the vapours of that acid, and that strong action of heat which the luted part is often obliged to sustain; of being easily applied, and in an uniform manner, without, too speedily becoming hard, induced me to make some researches, which furnished me with the most satisfactory result.

- From Annales de Cbimie, No. I3\%. 
After making a great number of mixtures with different substances, I thought it my duty to adopt the following, which gave me a homogeneous compound, which drying as slowly as could be desired, acquired very great hardness and became very compact, so as to have all the properties 1 wished for:

Take the whites of eggs with their yolks, carbonate of lime in powder, or lime strongly slaked in the air, equal in weight to about one half that of the eggs; and having put the whole on a piece of linen, apply it in the usual manner.

This luting, the composition of which is simple, possesses when dry a certain degree of elasticity. I have formed of it vessels impermeable to water, and susceptible of being polished by the lathe. In a word, this mixture resembles that substance called sea scum, of which tobacco pipes are made.

XLII. Accotent of the Travels of M. A. DE Humbold in South America, extracted from some of his Letters *

M. HumbondT's brother, who is now at Rome, received from him lately three letters: one dated Quito, June 3, 1802 ; another, Cuença, July 13, 1802; and the third, Lima;" the capital of Peru, November 25, 1802. They announce that M. Humboldt will soon return, and that he expected to land in the month of August or September at Cadiz, or Corunna; but the last of his letters in particular is the most interesting. In the following extract from it care has been taken to insert every thing worthy of attention in the other two :

MY DEAR BROTHER,

Lima, Nov. 25, 1802.

You must have learned by my preceding letters that $I$ had reached Quito, at which we arrived by traversing the snow of Quiridian and Tolima; for as the cordillera of the Andes forms three separate branches, and as we were atSanta Fé de Bogota, on that which is the most eastern, it was necessary to cross the highest to approach the coasts of the South Sea. Oxen are the only animals which can be employed in this passage for transporting baggage. Travellers in general are carried by men called largeros. They have a chair, in which the traveller is seated, tied to their back; they travel about four hours journey every day, and in five or six weeks earn only fourteen piastres. We preferred

* From Magazin Encyclopidique, Thermidor, an. $x$.

travelling 